Article

\title{
Influence of Gender on CMV Seropositivity in Non- A To G Hepatitis Virus Patients
}

\author{
Rand Farag 1,* , Dujana Alayobi ${ }^{2}$, Hye-Joo Kwon ${ }^{3}$, Afaf Elansary 4 \\ ${ }^{1}$ Assistant Prof of Virology and molecular microbiology, Health science Researches central, Princes \\ Nora University (PNU), Kingdom Saudi Arabia (KSA)p \\ ${ }_{2}^{2}$ Prof of Genetic, Biology department, Princes Nora University (PNU), Kingdom Saudi Arabia \\ (KSA); Prof.dujana@live.com \\ ${ }^{3}$ Assistant Prof of molecular biology, Biology department, Princes Nora University (PNU), \\ Kingdom Saudi Arabia (KSA); hjkwon@pnu.edu.sa \\ ${ }_{4}^{4}$ Prof Biochemistry, Central Labe, King Saud University (KSU); elansary@ksu.edu.sa \\ * Corresponding author: Randa792006@gmail.com; rmfarj@pnu.edu.sa_http://dx.doi.org/0000-0002-6705- \\ 0235
}

\begin{abstract}
Our study shows that females had much higher IgG and IgM compared to age-matching males. A significant correlation between both antibodies and liver enzymes (AST, ALT) was recorded. Less significant correlation of both IgG and IgM with GGT was also observed. Receiver operating characteristics (ROC) analysis revealed that both IgG and IgM can be used as excellent predictive markers for CMV infection as both recorded 100\% specificity and sensitivity together with area under the curve of 1 in males and females. Multiple regression analysis ascertain the correlation between both antibodies as dependent variables and liver enzymes as independent variables with ALT being the most affected enzyme with CMV seropositivity especially in females.This study shows that CMV is capable of initiating and accelerating liver dysfunction in both sexes. The high seroprevalence in females at reproductive age is especially important as they can transmit the virus to their developing fetus. Prevention of CMV infection in young girls 11-14 years old; the prevalence of congenital CMV infections may decreased by possible future vaccination and control on the most non-hepatorophic agent which developing liver dysfunction.
\end{abstract}

Keywords: cytomegalovirus; alanine transaminase; aspartate transaminase alkaline phosphatase; $\gamma$-glutamyltranspeptidase; liver function

\section{Background}

Cytomegalovirus (CMV) is an environmental pathogen that cause chronic infection, especially in high risk group patients. It is important to find risk factors associated with CMV viremia. We studied the differences in CMV seropositivity in relation to liver function biomarkers in male and female Saudi population in an attempt to understand the variation in the CMV seroprevalence with sex and find the risk factor to develop liver dysfunction which by the time caused changes in liver tissues.

\section{Introduction}

Cytomegalovirus (CMV) as an environmental virus that means have different routes of transmission so was detected with high prevalence rate (Pass, 1986; 1988; Adler, 1984, 1986). The main rout of CMV prevalence depending on socio-economic status, Geographical location (Marshall et al., 1993) age and gender (Ahlfors., 1984; Hizel , 1999 ). It is important to study the risk factors which depended on higher prevalence rate of CMV infection (Jhong-Lin, et al., 2015). In healthy individuals 
CMV infections are asymptomatic but in high risk group patients it caused serious complications (Ramanan and Razonable., 2013); CMV infection during pregnancy responsible on birth abnormalities such as brain damage and hearing loss (Picone et al., 2005); but the risk in females was detected higher than males (Dollard et al., 2007). In addition, the reported gender difference in CMV seroprevalence in females' responsible on infection of young children (Hecker et al., 2004). In another study by Staras et al (2008), occurred that CMV infection correlated with sexual activity; although viral titer in semen was lower than female secretions, which may explain the finding that females have higher rates of CMV infection compared to males.

Lopo et al., (2011) reported that in the older age groups females were more IgG-positive than males while IgG-positivity was equally common in males and females in the age groups of 2-4 and 5-9 year-olds. A statistically significant difference between males and females in the prevalence of CMV IgG seropositivity could be explained that women more contact with children (Schleiss., 2008; Staras et al., 2008a, Bale et al., 1999; staras et al., 2008 b). Cheng et al., (2009) and Lepiller et al., (2011) show that positively correlated with liver cirrhosis and CMV seroprevalence in patients with hepatocellular carcinoma (HCC) is significantly higher than in patients without HCC. This information motivates our interest to find the role of CMV infection in the risk of liver dysfunction in Saudi males and females hepatitis patients.

\section{Subjects and Methods}

\subsection{Study Population and Specimens}

The focus of our study was tested 455 serum samples for patients with elevation of liver profiles (ALT, AST, ALP and GGT) collected from different general hospitals and polyclinic in KSA from March 2014 to June 2015. Among these participants there were 150 patients (69 males and 81 females with average age of $28 \pm 14$ years), which was non- A to G hepatitis virus ( non HAV, HBV, HCV, HDV, HEV and HGV), where molecular technical for extraction of viruses nucleic acid, PCR and RTPCR were according to methods described by Lin, Z. and Floros, J. (2000); Centrifuged whole blood samples at 2,500 $\mathrm{g}$ for $10 \mathrm{~min}$, and sera were collected and stored at $-20^{\circ} \mathrm{C}$. The samples were coded by sample number, collection date, age and gender. Institutional Review Board (IRP) approval to perform the study was obtained from the College of Medicine, King Saud University, Riyadh, Kingdom of Saudi Arabia; Research project No.E-14-1116. Informed consent was obtained from all cases to the collection of specimens.

\subsection{Serology tests}

The CMV- IgG and IgM were screened in patients' sera by using a commercially available enzyme-linked immunosorbent assay (ELISA) (CMV IgG and CMV IgM, Dia. Pro; Diagnostic Bioprobes Srl, Italy). CMV antibody (IgG) with concentrations $\geq 1.10 \mathrm{IU} / \mathrm{ml}$ were positive samples and $\leq 0.9 \mathrm{IU} / \mathrm{ml}$ were negative; while the samples with concentrations $0.91-1.09 \mathrm{IU} / \mathrm{ml}$ were Equivocal. CMV-IgM antibody was considered positive with concentrations $>1.1 \mathrm{IU} / \mathrm{ml} ; 0.9-1.0$ Equivocal and $\leq 0.8$ No antibody detected. The samples optical density detected at $450 \mathrm{~nm}$ and ELISA assay results were analyzed in all samples included in the study.

\subsection{Statistical analysis}

The correlation between the CMV-IgG and IgM antibodies with different liver enzymes were detected by using A SPSS computer program analysis. Receiver Operating Characteristic (ROC) analysis was performed as a comprehensive way to measure the accuracy of the studied markers. Results were expressed as mean \pm SD and all statistical comparisons were made by means of independent $t$-test with $\mathrm{P} \leq 0.05$ considered as significant. The area under the curve (AUC) provides a useful metric to compare IgG and IgM as two CMV seropositivity markers. Whereas an AUC value close to 1 indicates an excellent diagnostic of specificity and sensitivity of the biomarker. Pearson's 
correlations was also presented. In this analysis $\mathrm{R}^{2}$ describes the percentage of variance in IgG and IgM (dependent variable) by the variance in AST, ALT, ALP and GGT (predictor variables). An R² of 1.00 indicates that $100 \%$ of the direct proportions between changes of dependent and independent variables. $\mathrm{R}^{2}$ and (B) coefficient provide most of what we need to interpret our multiple regression data.

\section{Results:}

Table 1 and figure 1 demonstrate the high significant elevations of AST, ALT and GGT together with the non-significant change in ALP. It can easily be noticed that both transaminases (AST and ALT) together with GGT were markedly higher in females than males recording 131, 144, and 110 percentage increase in females compared to 74,68 and 28 percentage increase in males respectively.

Table 1: Mean \pm S.D. of ALT, AST, ALP, GGT, IgG and IgM in male and female CMV seropositive Saudi patients compared to healthy control participants.

\begin{tabular}{|c|c|c|c|c|c|c|c|c|}
\hline Parameter & Gender & Group & $\mathrm{N}$ & Min. & Max. & Mean \pm S.D. & $\begin{array}{l}\text { Percent } \\
\text { Change }\end{array}$ & $P$ value \\
\hline \multirow{4}{*}{$\operatorname{ALT}(\mu / \mathrm{L})$} & \multirow{2}{*}{ Male } & Control & 14 & 24.74 & 55.80 & $38.23 \pm 8.23$ & 100.00 & \multirow{2}{*}{0.001} \\
\hline & & Patients & 69 & 56.04 & 112.40 & $66.79 \pm 12.07$ & 174.69 & \\
\hline & \multirow{2}{*}{ Female } & Control & 11 & 17.06 & 35.09 & $26.15 \pm 6.27$ & 100.00 & \multirow{2}{*}{0.001} \\
\hline & & Patients & 81 & 55.78 & 84.34 & $60.52 \pm 5.75$ & 231.40 & \\
\hline \multirow{4}{*}{$\operatorname{AST}(\mu / L)$} & \multirow{2}{*}{ Male } & Control & 14 & 12.56 & 32.90 & $26.04 \pm 5.39$ & 100.00 & \multirow{2}{*}{0.001} \\
\hline & & Patients & 69 & 35.23 & 66.78 & $44.01 \pm 6.74$ & 168.98 & \\
\hline & \multirow{2}{*}{ Female } & Control & 11 & 13.23 & 25.08 & $17.59 \pm 3.14$ & 100.00 & \multirow{2}{*}{0.001} \\
\hline & & Patients & 81 & 35.08 & 62.71 & $43.07 \pm 6.21$ & 244.81 & \\
\hline \multirow{4}{*}{ ALP (IU/L) } & \multirow[b]{2}{*}{ Male } & Control & 14 & 54.30 & 137.30 & $91.64 \pm 21.56$ & 100.00 & \multirow[b]{2}{*}{0.255} \\
\hline & & Patients & 69 & 45.02 & 148.20 & $81.49 \pm 31.61$ & 88.92 & \\
\hline & \multirow{2}{*}{ Female } & Control & 11 & 49.31 & 148.20 & $87.85 \pm 33.06$ & 100.00 & \multirow{2}{*}{0.919} \\
\hline & & Patients & 81 & 45.02 & 148.20 & $86.76 \pm 33.56$ & 98.75 & \\
\hline \multirow{4}{*}{ GGT $(\mu / \mathrm{L})$} & \multirow{2}{*}{ Male } & Control & 14 & 29.31 & 58.46 & $47.18 \pm 8.99$ & 100.00 & \multirow{2}{*}{0.001} \\
\hline & & Patients & 69 & 34.23 & 88.32 & $60.60 \pm 14.81$ & 128.46 & \\
\hline & \multirow{2}{*}{ Female } & Control & 11 & 12.02 & 42.02 & $28.74 \pm 9.76$ & 100.00 & \multirow{2}{*}{0.001} \\
\hline & & Patients & 81 & 34.23 & 88.32 & $60.53 \pm 13.96$ & 210.61 & \\
\hline \multirow{3}{*}{$\operatorname{Ig} G$} & \multirow{2}{*}{ Male } & Control & 14 & 0.14 & 0.82 & $0.40 \pm 0.20$ & 100.00 & \multirow{2}{*}{0.001} \\
\hline & & Patients & 69 & 4.05 & 23.28 & $10.52 \pm 4.73$ & 2617.28 & \\
\hline & Female & Control & 11 & 0.15 & 0.62 & $0.40 \pm 0.16$ & 100.00 & 0.001 \\
\hline
\end{tabular}


4 of 12

\begin{tabular}{|c|c|c|c|c|c|c|c|c|}
\hline \multirow{2}{*}{ Parameter } & Gender & Group & $\mathrm{N}$ & Min. & Max. & Mean \pm S.D. & $\begin{array}{l}\text { Percent } \\
\text { Change }\end{array}$ & P value \\
\hline \multirow{3}{*}{ IgM } & & Patients & 81 & 3.81 & 35.05 & $11.26 \pm 5.88$ & 2815.40 & \\
\cline { 3 - 10 } & \multirow{2}{*}{ Male } & Control & 14 & 0.10 & 0.52 & $0.26 \pm 0.12$ & 100.00 & \multirow{2}{*}{0.001} \\
\cline { 3 - 10 } & \multirow{2}{*}{ Female } & Patients & 69 & 12.04 & 53.40 & $21.87 \pm 7.26$ & 8388.11 & \multirow{2}{*}{0.001} \\
\cline { 3 - 10 } & & Control & 11 & 0.11 & 0.41 & $0.28 \pm 0.09$ & 100.00 & \\
\hline
\end{tabular}

- $\quad$ The independent T-Test between Patients groups in all parameters (Male - Female) and Control occurred by Table 1 .
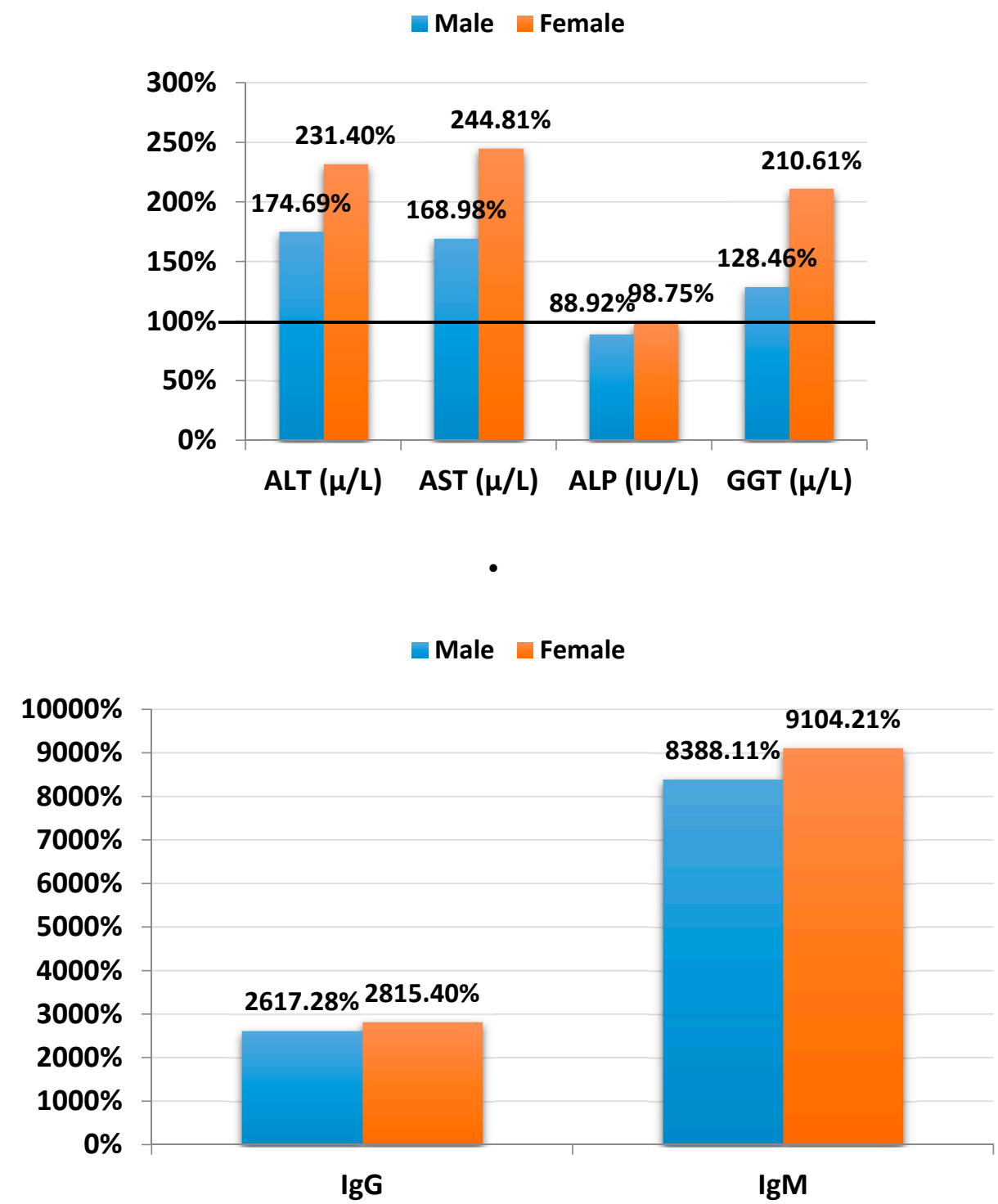

Fig. 1: Percentage change of all parameters male and female Saudi CMV seropositive patients compared to Control group. 
5 of 12

Table 2 and figure 2 show the significant correlations between both IgG and IgM as measure of CMV seropositivity. In addition significant correlations were also recorded between these two antibodies and AST, ALT, and GGT as measure of liver injury risk (e.g. liver cirrhosis).

Table 2: Pearson's correlations between the measured parameters

\begin{tabular}{|c|c|c|c|c|}
\hline Parameters & Gender & R (Person Correlation) & Sig. & \\
\hline \multirow{2}{*}{$\operatorname{IgG} \sim \operatorname{IgM}$} & Male & $0.739^{* *}$ & 0.001 & $\mathrm{~Pa}$ \\
\hline & Female & $0.756^{* *}$ & 0.001 & $\mathrm{~Pa}$ \\
\hline \multirow{2}{*}{$\operatorname{IgG} \sim \operatorname{ALT}(\mu / \mathrm{L})$} & Male & $0.545^{* *}$ & 0.001 & $\mathrm{~Pa}$ \\
\hline & Female & $0.620^{* *}$ & 0.001 & $\mathrm{~Pa}$ \\
\hline \multirow{2}{*}{$\operatorname{IgG} \sim \operatorname{AST}(\mu / L)$} & Male & $0.599^{* *}$ & 0.001 & $\mathrm{~Pa}$ \\
\hline & Female & $0.517^{* *}$ & 0.001 & $\mathrm{~Pa}$ \\
\hline \multirow{2}{*}{$\operatorname{IgG} \sim \operatorname{GGT}(\mu / \mathrm{L})$} & Male & $0.368^{* *}$ & 0.001 & $\mathrm{~Pa}$ \\
\hline & Female & $0.363^{* *}$ & 0.001 & $\mathrm{~Pa}$ \\
\hline \multirow{2}{*}{$\operatorname{IgM} \sim \operatorname{ALT}(\mu / L)$} & Male & $0.754^{* *}$ & 0.001 & $\mathrm{~Pa}$ \\
\hline & Female & $0.637^{* *}$ & 0.001 & $\mathrm{~Pa}$ \\
\hline \multirow{2}{*}{$\operatorname{IgM} \sim \operatorname{AST}(\mu / L)$} & Male & $0.655^{* *}$ & 0.001 & $\mathrm{~Pa}$ \\
\hline & Female & $0.525^{* *}$ & 0.001 & $\mathrm{~Pa}$ \\
\hline \multirow{2}{*}{$\operatorname{IgM} \sim \operatorname{GGT}(\mu / L)$} & Male & $0.527^{* *}$ & 0.001 & $\mathrm{~Pa}$ \\
\hline & Female & $0.465^{* *}$ & 0.001 & $\mathrm{~Pa}$ \\
\hline
\end{tabular}

Correlation is significant at the 0.01 level.

aPositive Correlation.
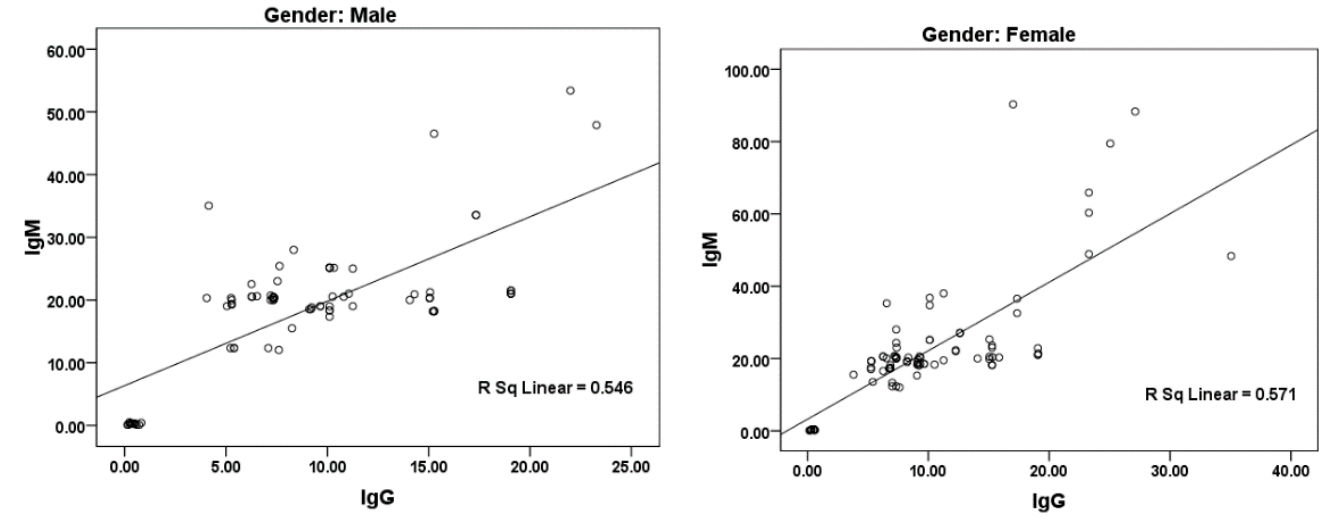
6 of 12
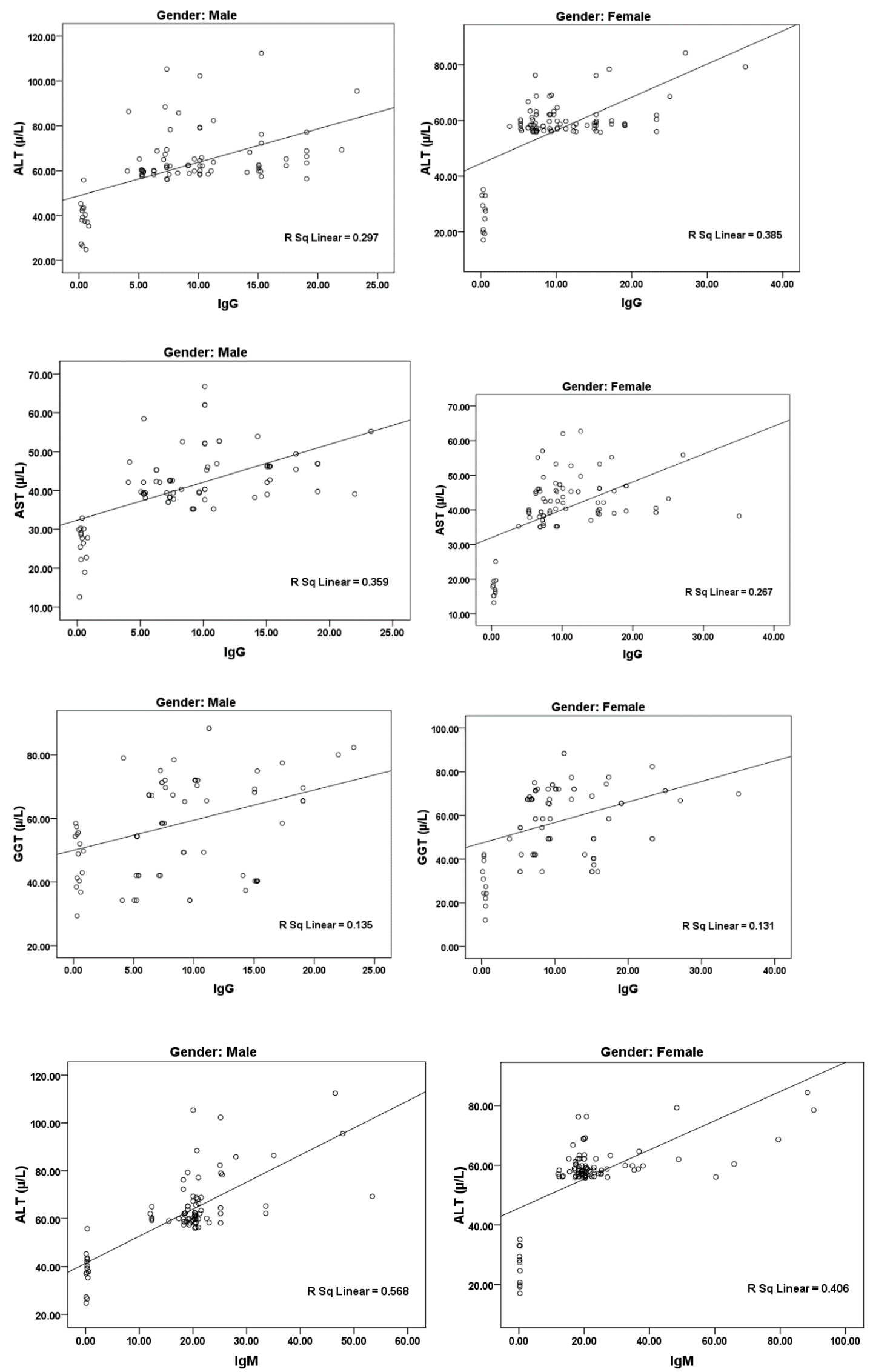

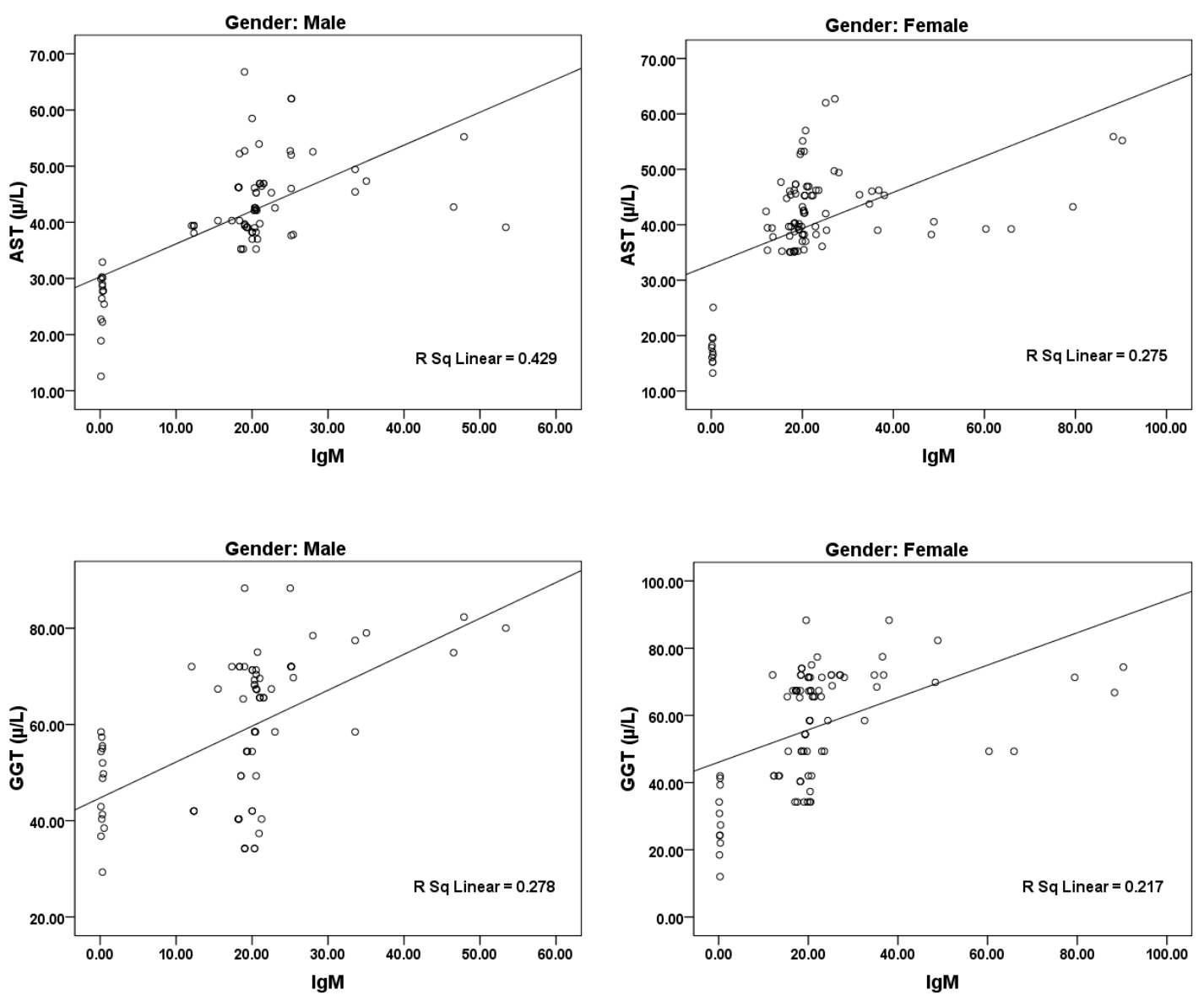

Fig. 2: Correlation between all parameters (Male - Female) with best fit line curve (positive correlation).

Table 3 and figure 3 represent the receiver operating characteristics (ROC) analysis of IgG and IgM in male and females CMV- seropositive patients. An area under the curve equal to 1 together with $100 \%$ sensitivity and specificity were recorded for both antibodies in male and female CMV patients.

Table 3: ROC-Curve of IgG and IgM (Male - Female) in Patients group

\begin{tabular}{|l|l|c|c|c|c|}
\hline \multirow{2}{*}{ IgG } & \multicolumn{1}{|c|}{ Group } & $\begin{array}{c}\text { Area under } \\
\text { the curve }\end{array}$ & $\begin{array}{c}\text { Cut-off } \\
\text { value }\end{array}$ & Sensitivity \% & Specificity \% \\
\hline \multirow{2}{*}{ IgM } & Male & 1.000 & 2.435 & $100.0 \%$ & $100.0 \%$ \\
\cline { 2 - 6 } & Female & 1.000 & 2.215 & $100.0 \%$ & $100.0 \%$ \\
\hline & Male & 1.000 & 6.280 & $100.0 \%$ & $100.0 \%$ \\
\cline { 2 - 6 } & Female & 1.000 & 6.225 & $100.0 \%$ & $100.0 \%$ \\
\hline
\end{tabular}



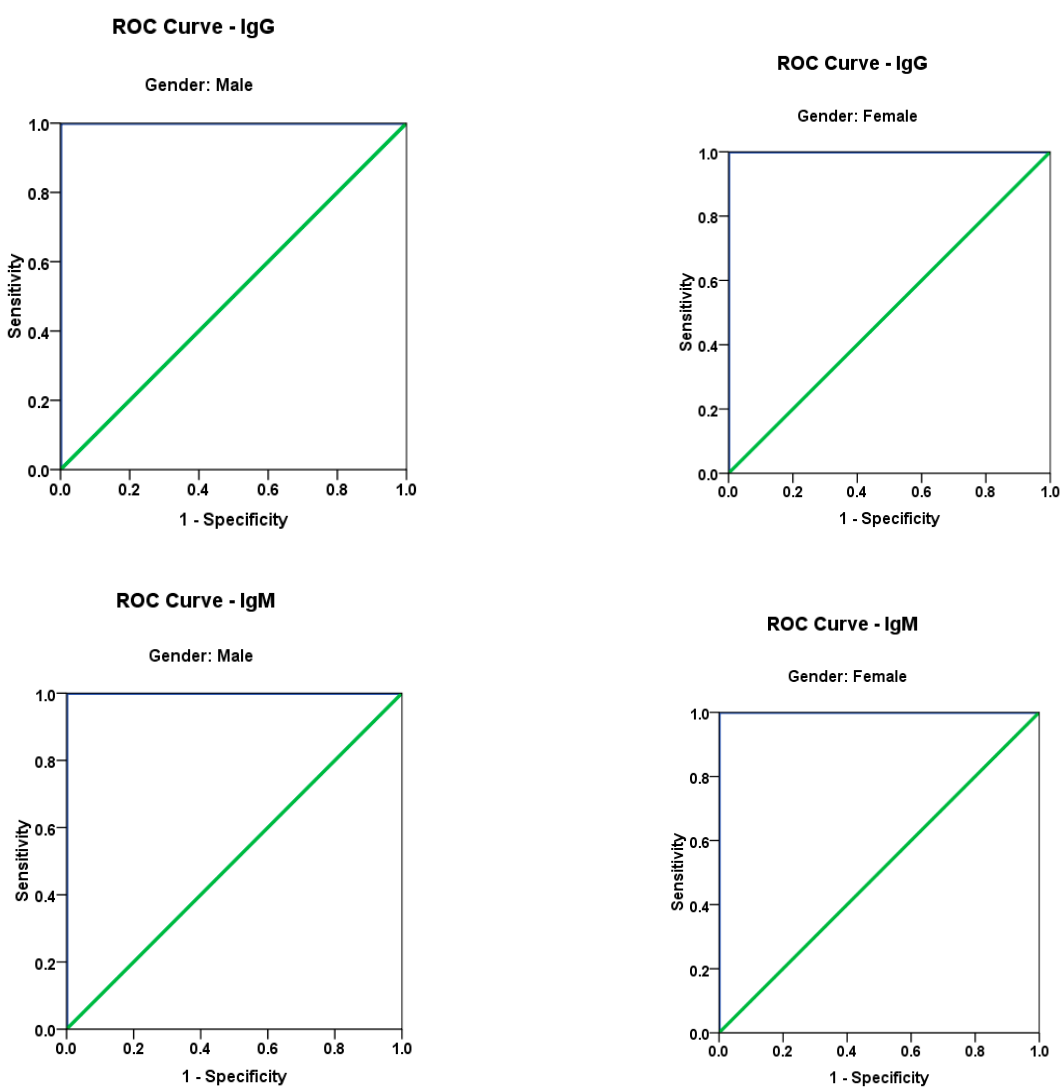

Fig. 3: ROC Curve of IgG and IgM (Male - Female) in Patients group.

Table 4 and 5 show the stepwise multiple regression analysis using $\operatorname{IgG}$ and $\operatorname{IgM}$ as dependent variable respectively and AST, ALT, ALP and GGT as independent variables. Adjusted $\mathrm{R}^{2}$ and $\mathrm{B}$ coefficients of the different variables are listed.

Table 4: Stepwise method for detection IgG variable

\begin{tabular}{|c|c|c|c|c|c|c|}
\hline \multirow{2}{*}{ Gender } & \multirow{2}{*}{ Predictor Variable } & \multirow{2}{*}{ Beta } & \multirow{2}{*}{ P value } & \multirow{2}{*}{$\begin{array}{c}\text { Adjusted R } \\
\text { square }\end{array}$} & \multicolumn{2}{|c|}{ Model } \\
\hline & & & & & $\mathrm{F}$ value & $P$ value \\
\hline \multirow{3}{*}{ Male } & $\operatorname{ALT}(\mu / \mathrm{L})$ & 0.367 & 0.001 & 0.351 & 45.307 & 0.001 \\
\hline & $\operatorname{AST}(\mu / L)$ & 0.374 & 0.001 & \multirow{3}{*}{0.392} & \multirow{3}{*}{27.41} & \multirow{3}{*}{0.001} \\
\hline & ALP (IU/L) & -0.042 & 0.013 & & & \\
\hline \multirow{2}{*}{ Female } & $\operatorname{ALP}(\mathrm{IU} / \mathrm{L})$ & -0.046 & 0.005 & & & \\
\hline & $\operatorname{ALT}(\mu / \mathrm{L})$ & 0.323 & 0.001 & 0.378 & 56.319 & 0.001 \\
\hline
\end{tabular}

Table 5: Stepwise method for detection the variable of IgM

\begin{tabular}{|l|l|l|l|l|l|l|}
\hline \multirow{2}{*}{ Gender } & Predictor Variable & Beta & P value & $\begin{array}{l}\text { Adjusted R } \\
\text { square }\end{array}$ & \multicolumn{2}{|l|}{ Model } \\
\cline { 4 - 7 } & & & & F value & P value \\
\hline Male & ALT $(\mu / \mathrm{L})$ & 0.503 & 0.001 & 0.563 & 106.657 & 0.001 \\
\hline
\end{tabular}




\begin{tabular}{|l|l|l|l|l|l|l|}
\hline \multirow{5}{*}{} & AST $(\mu / \mathrm{L})$ & 0.284 & 0.012 & & & \\
\cline { 2 - 7 } & GGT $(\mu / \mathrm{L})$ & 0.119 & 0.041 & & & \\
\cline { 2 - 7 } & ALP $(\mathrm{IU} / \mathrm{L})$ & -0.067 & 0.007 & & & \\
\hline Female & ALT $(\mu / \mathrm{L})$ & 0.830 & 0.001 & 0.399 & 61.389 & 0.001 \\
\hline
\end{tabular}

\section{Discussion}

CMV infection is major health problem and needs for strong preventive strategies; where's considered the common infectious virus cause complications in the immunocompetent individuals such as pregnant women, newborn infants, and recipients of bone marrow and organ transplants (Kundrotas and Clement., 1993 and Polo et al., 2011). The prevention strategy is depends on develop a vaccine that can be prevent primary infection during pregnancy by administered to women of childbearing age (Polo et al., 2011).

On other hand, there are four major types of laboratory abnormality-based liver injury usually include: hepatocellular, autoimmune, cholestatic, and infiltrative diseases. It is well known that persisting elevation of AST and ALT in asymptomatic patients is greatly related to high incidence of hepatocellular pattern of liver diseases (Kundrotas and Clement., 1999; Mathiesen et al., 1999); in addition the cholestasis and infiltrative patterns of liver injury, is usually diagnosed through the elevation of serum alkaline phosphatase (ALP) while markedly elevated bilirubin found in cholestatic diseases (Moseley 1996; Musana et al., 2004).

An even moderate but persistent increase in the level of aminotransferases is alarming and must always be investigated. Numerous liver diseases may silently progress to fibrosis and cirrhosis with elevated aminotransferases as the only manifestation (England et al., 2009). The remarkably higher increase of transaminases (AST and ALT) in female patients compared to males was described by Staras et al. (2006) and Hecker et al. (2004) in which they reported much higher CMV seropositivity in females compared to males in USA population. Their prevalence reports were show the correlation between CMV infection and sexual activity in women and high concentration of viral titer in semen (Lang and Kummer., 1972; Polo et al., 2011). This shows that females are at higher risk to develop liver dysfunction compared to males. Table 1 also demonstrates the significant elevation of GGT in both sexes with females reporting much higher GGT in plasma compared to males. Moreover the high prevalence of CMV seropositivity together with the noticeable elevation of both transaminases can be linked to our recent unpublished work which recorded higher seropositivity, hypertransaminasemia, in 18-25 age groups compared to elder groups (26-35 \& 36-45). Of course, higher sexual activities are more common in this age category compared to the other 2 age groups.

Table 1 also demonstrates significantly higher levels of IgG and IgM in CMV seropositive patients of both sexes with female patients showing much higher antibodies compare to males. This results occurred disagree with Lopo et al. (2011) who's recorded that IgG-positivity was equally common in both sexes in young age groups of 2-4 and 5-9 year-olds. This contradictory can be explained on the bases of the studied age groups. The 2-4 and 5-9 age groups of Polo research group are far enough from sexual activities which significantly associated with CMV seropositivity in females. In the present study, the statistically significant $(7.57 \%)$ higher IgG in females compared to males. Again this recorded percentage increase was consistent with that recorded by Polo et al., (2011) which reported a significantly $8 \%$ much higher IgG in females than males. That explain the correlation between higher risk to mothers, pregnant women, and exposure to children (Bale et al., 1999; Schleiss, 2008; Staras et al., 2008;). 
On the other hand, the number of infants who acquire CMV infection during the first year of life due to CMV seropositive in breastfeed mothers. It is well documented that in countries where breastfeeding is widely practiced such as Saudi Arabia and most of mothers are seropositive, a high percentage of infants acquire CMV within the first year of life (Pass et al., 2001; Arvin et al., 2004).

Table 2 and figure 2 demonstrate Pearson's correlations between liver enzymes in one hand and CMV seropositivity markers on the other hand. It can be easily noticed that both antibodies were positively correlated with high significant difference. This can suggest the predictive value of both as markers of CMV seropositivity. In addition IgG and IgM were independently correlated with the four measured liver enzymes which can confirm the concomitant liver dysfunction usually associated with CMV viremia. This agree with other studied (Cheng, et. al., 2009 and Serghini, et. al., 2014) which prove that CMV infection usually induces autoimmune hepatitis and primary biliary cirrhosis. Moreover it can explain the earlier report of Marinelli et al (1993) which prove that there is a link between CMV infection and the chronic, active diseases of the liver. CMV infection appears to produce pathological lesions predominantly in the lobules and thus there is a similarity between CMV and HCV, which is thought to bring about a chronic lobular hepatitis (Henson et al., 1974; Myerson et al 1984). Additionally, CMV brings about damage to the sinusoidal wall; increasing the levels of white cells which come in contact with the liver cell membrane (Di Bisceglie et al., 1984). This can explain the high significant positive correlation between CMV antibodies and AST, ALT and GGT in the male and female CMV positive Saudi patients. So this study suggested that by detection of CMV-specific humoral immunity, may control and prevention CMV infection in CMVseropositive patients especially in pregnant women.

In a ROC curve, the sensitivity of a measured variables is plotted as a function of the false positive rate (100-Specificity) for different cut-off points. So ROC curve as a perfect statistical analytic for the evaluation of the predictive values of biomarkers was performed using the same computer program. In the present study, the area under the ROC curve is a measure of how well a parameter can distinguish between CMV seropositive and control healthy participants. The area under the curve (AUC) provides a useful measure to compare different biomarkers. Whereas an AUC value close to 1 indicates an excellent diagnostic and predictive marker, a curve with $\mathrm{AUC}=0.5$ has no diagnostic utility. AUC close to 1 is always accompanied by satisfactory values of specificity and sensitivity of the biomarker. Based on this information, IgG and IgM can be used as excellent predictive markers for CMV infection in female and male CMV seropositive Saudi patients.

In the present study, the general purpose of multiple regressions is occurs the relationship between several independent variables (AST, ALT, ALP and GGT) and a dependent variable (IgG or IgM) through the recorded $R^{2}$ and $B$ coefficient values. An $R^{2}$ of 1.00 indicates that $100 \%$ detected variation between studding parameters. Conversely, an $\mathrm{R}^{2}$ of 0.0 indicates the absence of this variation. The $B$ coefficients values show the direction either positive or negative and the contribution of the independent variable relative to the other independent variables in explaining the variation of the dependent variable. $R^{2}$ and $(ß)$ coefficient provide most of what we need to interpret our multiple regression data.

Table 4 and 5 demonstrate the linear regression analysis between the measured parameters using $\operatorname{IgG}$ and IgM as dependent variables respectively. It can be easily noticed that IgG and IgM both show low $\mathrm{R}^{2}$ values. This was expected as $\mathrm{CMV}$ as viral infectious disease never induced due to liver dysfunction. On the other hand, $\mathrm{B}$ coefficients values for AST, ALT. and GGT as independent variables point to ALT as the most important enzyme related to CMV seropositivity measured as high IgG and IgM. ALT recorded B coefficients values of 0.83 in CMV positive female patients which ascertain the increased CMV seroprevlence in females than males.

Many studies reported that CMV seroprevalence is much higher in patients with hepatocellular carcinoma (HCC) than in patients without HCC and is positively correlated with liver cirrhosis (Gredmark, et al., 2007; Kokudo and Makuuchi 2009 and Lepiller, et al., 2011). In relation to this phenomenon, elimination of CMV seroprevalence may reduce HCC mortality rates.

Clinical trials of CMV-vaccine candidates have shown promise, with several candidates in various stages of testing (Wloch et al., 2008; Schleiss, 2013; Pass and Anderson, 2014). In 2009, Pass et 
al. reported promising results from a Phase II trial of one of these candidate vaccines demonstrating reasonable $(\sim 50 \%)$ vaccine efficacy in preventing maternal CMV infection. Because the primary burden of $\mathrm{CMV}$ infection is in the developing fetus, a reasonable target population for CMV vaccination may be young adolescent females. So, may need to be tailored to suit the needs of different populations for prevent primary CMV infection in pregnant women. Based on this information and the obtained data of the present study, we can conclude that, vaccination of young girls would ensure that the vast majority of these females would be protected prior to any pregnancies and thus reduce the CMV prevalence and its risk factors.

Acknowledgements: The authors would like to thank King Abdul Aziz City for Science and Technology (KACST) for supporting the present work as part of NTPC funded projects No. AT-34-208. Our gratitude is also extended to Princess Nora University (PNU) and King Saud University for provided the infrastructure and facilities required for performing this work successfully. Also my great thanks for prof. Afaf EL-ansary for review the paper and for all work tem.

\section{REFERENCES:}

1.Henson DE, Grimley RM, Strano AJ: Post-natal cytomegalovirus hepatitis. Hum Patho11974; 5: 93 -103.

2.Myerson D, Hackman RC, Nelson JA, et a1: Widespread presence of histologically occult cytomegalovirus. Hum Path 01 1984; 15: 430- 439.

3.Di Bisceglie AM, Goodman ZD, Ishak KG, et a1: Long-term clinical and histopatol ogical follow-up of chronic posttrans- fusion hepatitis. Hepatology1991; 14: 969- 974.

4.Pass, RF. Cytomegalovirus. In: Knipe DM, Howley PM, editors field's Virology. 4th ed. Philadelphia: Lippincott William Wilkins, 2001 P. 2657-705.

5.Arvin AM, Fast P, Myers M, Plotkin S, Rabinovich R. Vaccine development to prevent cytomegalovirus disease: report from the National Vaccine Advisory Committee. Vaccines Clin Infect Dis. 2004; 39(2):233-9.

6.Marinelli RM, Delle Monache M, Gerardi R, Berardo C, Santolamazza M, Bruno G, Ricci GL. Liver pathology in cytomegalovirus infection associated with hepatitis B virus. J Int Med Res. 1993 May-Jun;21(3):154-7.

7.England K, Thorne C, Pembrey L, Tovo PA, Newell ML. Age- and sex-related reference ranges of alanine aminotransferase levels in children: European paediatric HCV network. J Pediatr Gastroenterol Nutr 2009; 49:71-7

8.Staras SA, Dollard SC, Radford KW, Flanders WD, Pass RF, Cannon MJ. Seroprevalence of cytomegalovirus infection in the United States, 1988-1994. Clin Infect Dis 2006; 43(9):1143-1151.

9.Lang DJ, Kummer JF. Demonstration of cytomegalovirus in semen. N Engl J Med 1972; 287(15):756-758.

10.Hecker M, Qiu D, Marquardt K, Bein G, Hackstein H. Continuous cytomegalovirus Musana KA, Yale SH, and Abdulkarim A.S, Tests of Liver Injury. Clin Med Res. 2004; 2(2): 129-131.

11.Moseley RH. Evaluation of abnormal liver function tests. Med Clin North Am 1996; 80:887-906

12.Kundrotas LW, Clement DJ. Serum alanine aminotransferase (ALT) elevation in asymptomatic US Air Force basic trainee blood donors. Dig Dis Sci 1993; 38:2145-2150.

13.Mathiesen UL, Franzen LE, Fryden A, Foberg U, Bodemar G.The clinical significance of slightly to moderately increased liver transaminase values in asymptomatic patients. Scand J Gastroenterol 1999; 34: 85-91.

14.Schleiss MR. Congenital cytomegalovirus infection: Update on management strategies. Curr Treat Options Neurol. 2008;10(3):186-92.

15.Staras S, Flanders WD, Dollard SC, Pass RF, McGowan JE, Cannon MJ. Influence of sexual activity on cytomegalovirus seroprevalence in the United States, 1988-1994. Sex Transm Dis. 2008;35(5):42-9.

16.Bale JF Jr, Zimmerman B, Dawson JD, Souza IE, Petheram SJ, Murph JR. Cytomegalovirus transmission in child care homes. Arch Pediatr Adolesc Med. 1999;153(1):75-9.

17.Staras SA, Flanders WD, Dollard SC, Pass RF, McGowan JE Jr, Cannon MJ. Cytomegalovirus seroprevalence and childhood sources of infection: a population-based study among pre-adolescents in the United States. J Clin Virol. 2008;43(3):266-71.

18.Lopo S, Vinagre E, Palminha P, Paixao MT, Nogueira P, Freitas MG. Seroprevalence to cytomegalovirus in the Portuguese population, 2002-2003. Euro Surveill. 2011 Jun 23;16(25).

19.Picone O, Costa JM, Dejean A, Ville Y. Is fetal gender a risk factor for severe congenital cytomegalovirus infection? Prenat Diagn 2005;25:34-8.

20.Jhong-Lin Wu, Hsuan-Yin Ma, Chun-Yi Lu, Jong-Min Chen, Ping-Ing Lee, Shiann-Tarng Jou, Yung-Lin Yang, Hsiu-Hao Chang, Meng-Yao Lu, Luan-Ying Chang, Li-Min Huang. (2015). Risk Factors and Outcomes of 
Cytomegalovirus Viremia in Pediatric Hematopoietic Stem Cell Transplantation Patients Journal of Microbiology, Immunology and Infection, In Press, Accepted Manuscript, Available online 14 August.

21.Dollard SC, Grosse SD, Ross DS. New estimates of the prevalence of neurological and sensory sequelae and mortality associated with congenital cytomegalovirus infection. Rev Med Virol 2007; 17:355-63.

22.Ramanan P,Razonable RR .Cytomegalovirusinfectionsinsolidorgantransplan- tation: a review. Infect Chemother 2013; 45:260-71.

23.Staras SA, Flanders WD, Dollard SC, Pass RF, McGowan JE Jr, Cannon MJ. Influence of sexual activity on cytomegalovirus seroprevalence in the United States, 1988-1994. Sex Transm Dis 2008; 35(5):472-479.

24.Lang DJ, Kummer JF. Demonstration of cytomegalovirus in semen. N Engl J Med 1972; 287(15):756-758

25.Hecker M, Qiu D, Marquardt K, Bein G, Hackstein H. Continuouscytomegalovirus seroconversion in a large group of healthy blood donors. Vox Sang 2004; 86(1):41-44.

26.Pass RF, Hutto C, Ricks R, Cloud GA(1986) Increased rate of cytomegalovirus infection among parents of children attending day-care centers. N Engl J Med 314:1414-8.

27.Adler SP (1988) Molecular epidemiology of cytomegalovirus: viral transmission among children attending a day care center, their parents, and caretakers. J Pediatr 112:366-72.

28.Adler SP(1986) Molecular epidemiology of cytomegalovirus: evidence for viral transmission to parents from children infected at a day care center. Pediatr Infect Dis 5:315-8

29.Pass RF, Hutto SC, Reynolds DW, Polhill RB (1984) Increased frequency of cytomegalovirus infection in children in group day care. Pediatrics 74:121-6.

30.Marshall GS, Rabalais GP, Stewart JA, Dobbins JG(1993) Cytomegalovirus seroprevalence in women bearing children in Jefferson County, Kentucky. Am J Med Sci 305:292-6.

31.Ahlfors K (1984) IgG antibodies to cytomegalovirus in a normal urban Swedish population. Scand J Infect Dis 16:335-7.

32.Hizel S, Parker S, Onde U(1999) Seroprevalence of cytomegalovirus infection among children and females in Ankara, Turkey, 1995. Pediatr Int 41:506-9.

33.Gredmark, S., Jonasson, L., Van Gosliga, D., Ernerudh, J. and Sderberg-Naucler, C. (2007). Active cytomegalovirus replication in patients with coronary disease. Scand Cardiovasc J, 41:230-234.

34.Kokudo, N. and Makuuchi, M. (2009). Evidence-based clinical practice guidelines for hepatocellular carcinoma in Japan: the JHCC guidelines. J Gastroenterol.;44 :119-21.

35.Lepiller, Q., Tripathy, M. K., Martino, V. D., Kantelip, B. and Herbein, G. (2011). Increased HCMV seroprevalence in patients with hepatocellular carcinoma. Virol J.; 8: 485.

36.Pass RF, Zhang C, Evans A, Simpson T, Andrews W, Huang ML, et al. Vaccine prevention of maternal cytomegalovirus infection. New England Journal of Medicine2009; 360 (12): 1191-9.

37.Wloch MK, Smith LR, Boutsaboualoy S, Reyes L, Han C, Kehler J, Smith HD, Selk L, Nakamura R, Brown JM, Marbury T, Wald A, Rolland A, Kaslow D, Evans T, Boeckh M. Safety and immunogenicity of a bivalent cytomegalovirus DNA vaccine in healthy adult subjects. J Infect Dis. 2008 Jun 15;197(12):1634-42.

38.Schleiss MR.Cytomegalovirus in the neonate: immune correlates of infection and protection. Clin Dev Immunol. 2013; 50: 1801.

39.Pass RF, Anderson B. Mother-to-Child Transmission of Cytomegalovirus and Prevention of Congenital Infection. J Pediatric Infect Dis Soc. 2014 Sep;3(Suppl 1):S2-S6.

(C) 2016 by the authors; licensee Preprints, Basel, Switzerland. This article is an open access article distributed under the terms and conditions of the Creative Commons by Attribution (CC-BY) license (http://creativecommons.org/licenses/by/4.0/). 